\title{
PENGARUH SERVICE QUALITY, SATISFACTION, DAN PERCEIVED SWITCHING COST TERHADAP CUSTOMER LOYALTY OPERATOR SELULER
}

\author{
Tommy Setiawan Ruslim \\ Henryanto Wijaya \\ Halim Putera Siswanto \\ Hadi Cahyadi \\ Universitas Tarumanegara \\ henryanto.wijaya@gmail.com
}

\begin{abstract}
:
The need for cell phone use can be said to be a necessity that cannot be avoided anymore in this day and age, both its use in communicating in business needs, personal needs to social relations with others. The importance of maintaining customer loyalty is very significant to the survival of a company, to maintain customer loyalty many variables that can influence it. This study examines the effect of service quality, customer satisfaction, perceived switching cost on customer loyalty of " $X$ " mobile operator users at a university in West Jakarta. In this research, it was founded that was a positive and significant effect service quality, customer satisfaction, perceived switching cost on customer loyalty of " $X$ " mobile operator users at a university in West Jakarta.
\end{abstract}

Keywords : Serqual, Satisfaction, Switching, Loyalty

\section{PENDAHULUAN}

Kebutuhan akan penggunaan ponsel dapat dikatakan merupakan sebuah kebutuhan yang tidak dapat dihindari lagi di zaman sekarang ini, baik penggunaannya dalam berkomunikasi dalam keperluan bisnis, keperluan pribadi sampai hubungan sosial dengan orang lain. Di Indonesia terdapat beberapa operator seluler yang menyajikan berbagai penawaran produk mereka dengan harga dan kualitas yang berbeda-beda. Untuk itu masingmasing operator seluler untuk dapat bersaing, mereka harus memberikan yang terbaik untuk konsumennya. Pentingnya menjaga loyalitas konsumen sangatlah signifikan terhadap kelangsungan hidup suatu perusahaan, untuk menjaga loyalitas konsumen 
banyak variabel-variabel yang bisa mempengaruhinya. Dalam hal industri operator seluler, kecepatan browsing menjadi salah satu kunci penting, karena banyak konsumen sekarang membutuhkan kecepatan internet untuk melakukan aktivitas mereka masingmasing baik untuk melakukan pekerjaan, youtube, bermain game, dsb. Dari data yang diperoleh dari tekno.kompas.com, terlampir pada gambar 1:

Gambar 1 Laporan Jaringan Seluler Juli 2019

Pengalaman Kecepatan Pengunduhan dalam Mbps
OPENSIONAL

\section{8}

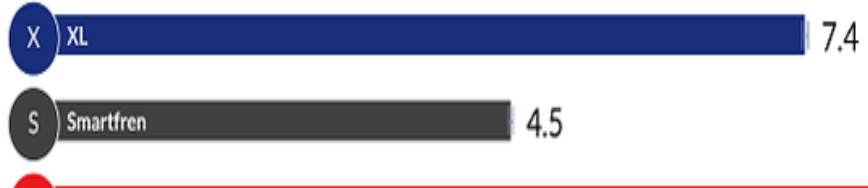

T Telkomsel

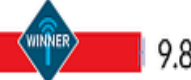

$3 \longdiv { 3 }$

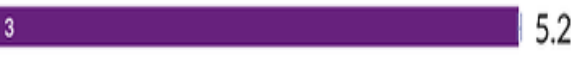

5.2
Dengan memperhatikan tabel di atas dapat dilihat kualitas kecepatan pengunduhan dari masing-masing operator selular, setiap konsumen tentunya menginginkan yang terbaik dalam penggunaan produk mereka sendiri. Oleh karena itu kepuasan merupakan faktor yang sangat penting dalam menjaga sebuah loyalitas yang baik dari konsumen itu sendiri, dengan kepuasan penggunaan produk yang bersangkutan diharapkan membuat konsumen menjadi loyal terhadap produk tersebut. Service quality yang baik juga dipercaya dapat meningkatkan loyalitas konsumen seperti yang dilakukan oleh Santouridis dan Trivellas (2010) meneliti tentang service quality pengguna operator seluler terhadap loyalitas, dengan 
mengukur service quality dari segi network, value added-services, mobile devices, customer services, pricing structure, billing system. Tarus \& Rabach (2013) meneliti satisfaction pengguna operator selular di Kenya terhadap loyalitas konsumen, yang dinilai dari kepuasan terhadap pelayanan yang ditawarkan, menunjukan pentingnya menjaga kepuasan konsumen untuk kelangsungan loyalitas suatu perusahaan. Perpindahan operator seluler akibat dampak dari harga yang berbeda yang ditawarkan oleh pesaingnya juga menjadi faktor yang tidak kalah penting dalam menentukan loyalitas konsumen, mengingat perekonomian yang tidak menentu bisa membuat sejumlah konsumen untuk berpindah dari penggunaan operator yang sebelumnya digunakan untuk berganti ke operator lainnya. Apabila operator pesaing menawarkan harga yang lebih murah mungkin bisa menyebabkan konsumen untuk berpindah menggunakan operator seluler tersebut. Fenomena operator seluler di Indonesia menjadi hal yang menarik untuk diteliti dengan melihat sejumlah perusahaan yang sedang mengalami penurunan untuk diteliti tentang loyalitas konsumennya. Oleh karena itu peneliti berniat membuat penelitian yang berjudul "Pengaruh service quality, satisfaction, perceived switching cost terhadap customer loyalty operator seluler.

Perumusan Masalah

Berdasarkan permasalahan di atas, maka perumusan masalah dalam penelitian ini adalah sebagai berikut :

a) Apakah service quality memiliki pengaruh terhadap customer loyalty?

b) Apakah customer satisfaction memiliki pengaruh terhadap customer loyalty?

c) Apakah perceived switching cost memiliki pengaruh terhadap customer loyalty?

Batasan Masalah

Penelitian ini memiliki batasan dari segi ruang lingkup penelitian menggunakan mahasiswa di sebuah universitas di Jakarta Barat yang menggunakan operator seluler merek "X", dengan periode pembagian sampel pada bulan Oktober-November 2019. 
Tujuan Penelitian

Tujuan dari penelitian ini adalah sebagai berikut :

a) Untuk mengetahui apakah service quality memiliki pengaruh terhadap customer loyalty.

b) Untuk mengetahui apakah

\section{TELAAH LITERATUR}

Service Quality.

Menurut Ganguli \& Roy (2011), definisi service quality adalah sebagai berikut : "Service quality has been defined in services marketing literature as an overall assessment of service by the customers". Kotler \& Keller (2006) dalam Hafeez \& Muhammad (2012) mendefinisikan service quality sebagai berikut : "Service is kind of performance that is offered by one party to another and in corporeality is a must part of it". Dari definisi di atas dapat disimpulkan bahwa service quality adalah pelayanan adalah kinerja yang ditawarkan sebagai keseluruhan penilaiannya dari konsumen.

\section{Satisfaction.}

Andaleeb \& Conway (2006), mendefinisikan kepuasan konsumen sebagai"the overall level of contentment customer satisfaction memiliki pengaruh terhadap customer loyalty.

c) Untuk mengetahui apakah perceived switching cost memiliki pengaruh terhadap customer loyalty.

with a service/product experience". Sedangkan, Tuan \& Linh (2014), mendefinisikan "customer satisfaction is defined as the levels of service quality performances that meet customers' expectations". Dari definisi di atas dapat disimpulkan bahwa kepuasan adalah tingkat pengalaman seseorang atau kualitas pelayanan yang diberikan terhadap ekspektasi dari produk/ jasa tersebut.

Switching Cost.

Avgeropoulos \& Bonnici (2014), mendefinisikan switching cost sebagai berikut : "Switching costs are the costs that consumers face in order to change between substitute products". Heide \& John dalam Shah, et al. (2013), mendefinisikan switching cost sebagai berikut : "switching costs are exacerbated by idiosyncratic investments, that is, investments that are 
difficult to switch to another relationship". Dari definisi di atas dapat disimpulkan bahwa switching cost adalah biaya yang dihadapi konsumen ketika mengganti suatu produk, investasi yang sulit untuk berpindah ke yang lainnya.

Customer loyalty.

Definisi loyalitas menurut Thakur (2016) dalam Alhaija , et al. (2018), adalah : "loyalty as a customers' intention to remain committed to specific provider in the marketplace by repeating their purchasing experiences". Kim \& Yoon (2004) dalam Khan (2012), mendefinisikan loyalitas konsumen sebagai berikut : "Customer loyalty has been defined early that, it is normally the willingness of customer to maintain their relations with a particular firm or service/product". Dari definisi di atas, dapat disimpulkan loyalitas adalah intensitas konsumen untuk terus menggunakan produknya dengan melakukan pembelian berulang dengan penggunaan produk yang sama.
Keterkaitan service quality terhadap customer loyalty.

Pada penelitian yang dilakukan oleh Santouridis dan Trivellas (2010) yang meneliti tentang pengaruh service quality terhadap loyalitas konsumen operator seluler di Yunani, dengan mengambil 205 sampel yang valid dengan menggunakan kuesioner, service quality dalam hal network, value addedservices, mobile devices, customer services, pricing structure, billing system. Diperoleh hasil bahwa service quality berpengaruh positif terhadap loyalitas konsumen.

Keterkaitan satisfaction terhadap customer loyalty.

Tarus dan Rabach (2013) dalam penelitiannya meneliti tentang operator seluler di Kenya, dalam penelitiannya diambil sampel sebanyak 300 responden di mana hanya sebanyak 140 data yang digunakan dalam penelitiannya. Dari hasil penelitiannya diperoleh bahwa customer satisfaction berpengaruh positif terhadap customer loyalty pada pengguna operator seluler di Kenya. 
Keterkaitan perceived switching cost terhadap customer loyalty

Qayyum, Khang \& Krairit (2013), meneliti tentang pentingnya perceived switching cost pada customer loyalty pengguna operator selular di provinsi Punjab negara Pakistan, dengan mengambil sampel sebanyak 700

\section{METODOLOGI PENELITIAN}

Aritonang (2007) menjelaskan definisikan populasi sebagai seluruh unsur subjek penelitian atau disebut juga universe. Yang menjadi populasi dalam penelitian in adalah seluruh konsumen pengguna layanan operator "X". Karena banyaknya populasi tersebut, maka peneliti mengambil sampel di sebuah universitas yang ada di Jakarta Barat. Ada pun metode pengambilan sampel dalam penelitian ini menggunakan metode metode tidak acak (non-probability sampling). Dengan teknik pengambilan sampel kuesioner yang disebar, sebanyak 594 yang kembali dan diolah datanya. Dalam penelitiannya perceived switching cost terhadap customer loyalty terdapat pengaruh positif dan signifikan.

convenience sampling, Nasution \& Usman (2007) menjelaskan bahwa convenience sampling dilaksanakan terhadap "kenyamanan" berkaitan dengan penyediaan data yang dibutuhkan. Sampel yang diambil dalam penelitian ini adalah sebanyak 50 responden, di mana ukuran pengambilan sampel ini mengacu pada Roscoe (1975) dalam Uma Serakan (2013) yaitu ukuran sampel yang ideal untuk dilakukannya sebuah penelitian adalah lebih dari 30 atau kurang dari 500 . 
Tabel 1 Indikator Service Quality $\left(\mathrm{X}_{1}\right)$

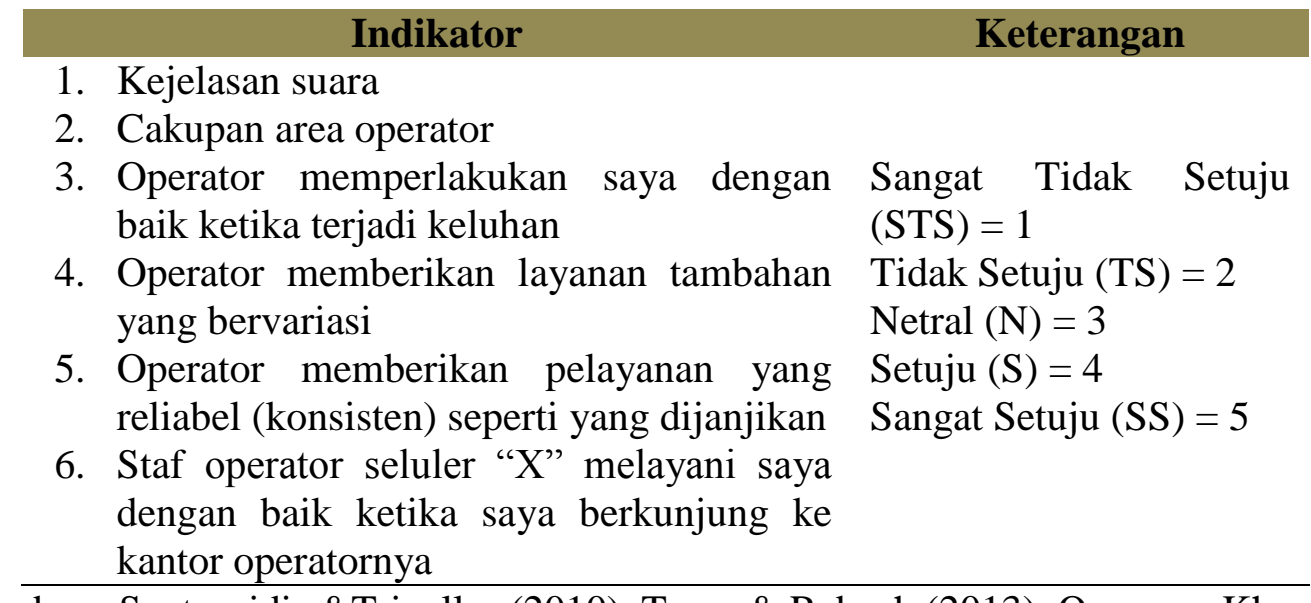

Sumber : Santouridis \&Trivellas (2010), Tarus \& Rabach (2013), Qayyum, Khang \& Krairit (2013

Tabel 2 Indikator satisfaction $\left(\mathrm{X}_{2}\right)$

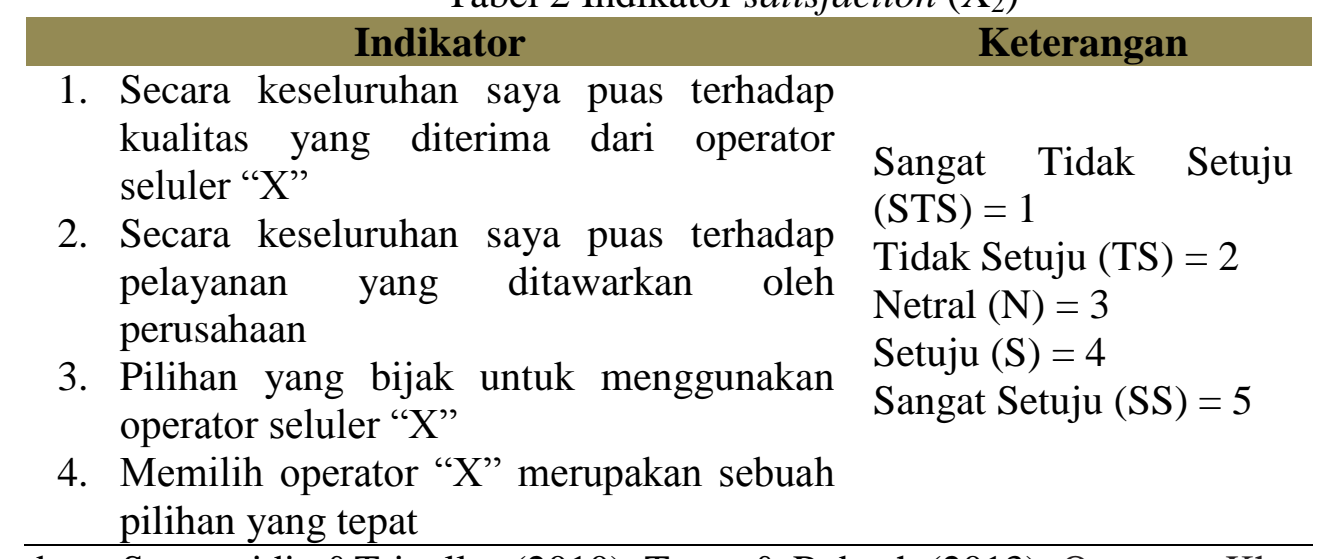

Sumber : Santouridis \&Trivellas (2010), Tarus \& Rabach (2013), Qayyum, Khang \& Krairit (2013) 
Tabel 3 Indikator perceived switching cost $\left(\mathrm{X}_{3}\right)$

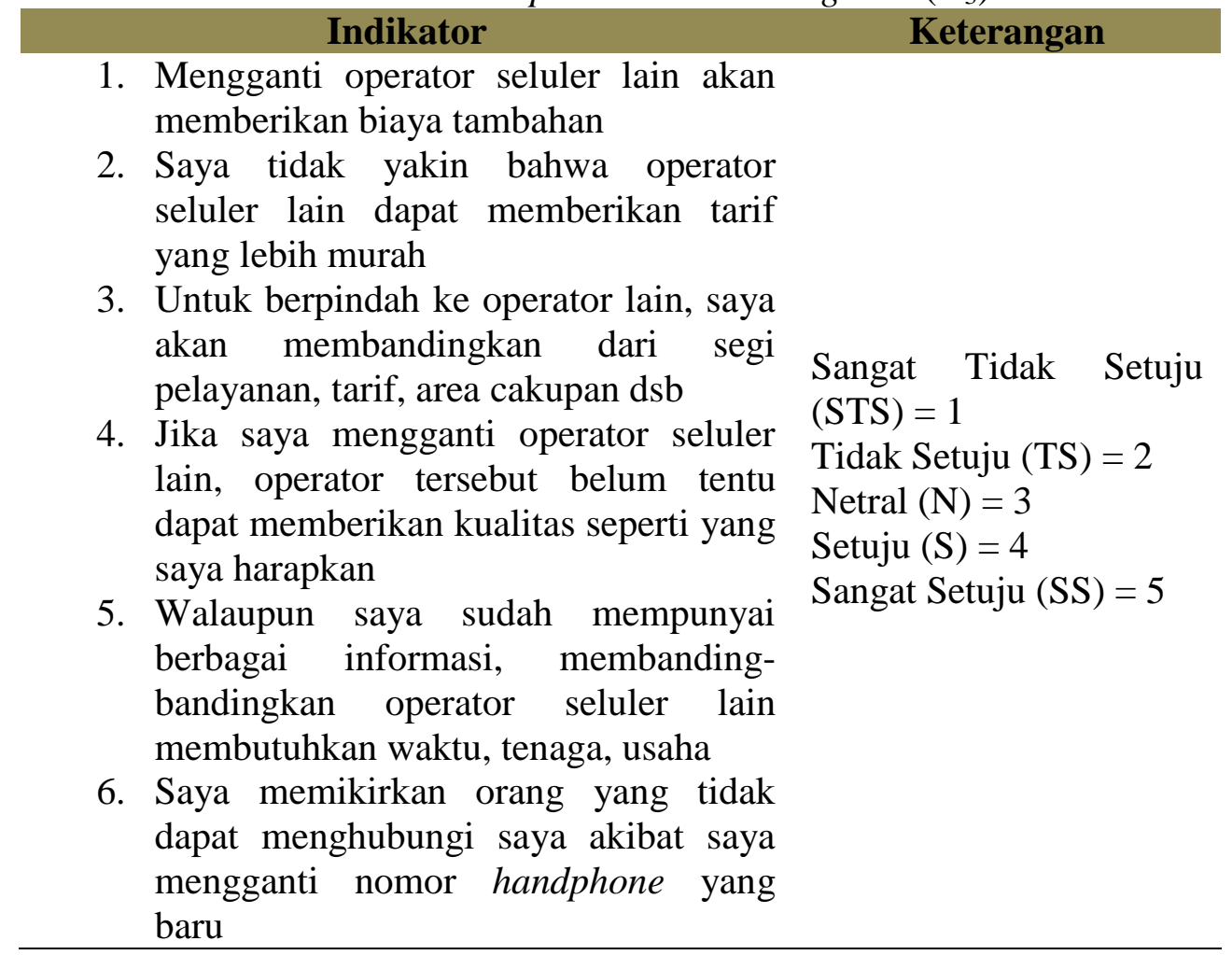

Sumber : Qayyum, Khang \& Krairit (2013)

Tabel 4 Indikator Customer loyalty (Y)

\section{Indikator}

Keterangan

1. Saya akan merekomendasikan operator seluler " $X$ " ke orang lain

2. Saya akan terus menggunakan operator Sangat Tidak Setuju seluler " $X$ "

$(\mathrm{STS})=1$

3. Walaupun operator merek lain lebih Tidak Setuju (TS) $=2$ murah, saya akan tetap menggunakan $\operatorname{Netral}(\mathrm{N})=3$ operator seluler " $\mathrm{X}$ "

Setuju $(\mathrm{S})=4$

4. Jika saya membeli nomor handphone Sangat Setuju $(\mathrm{SS})=5$ baru, saya akan memilih operator seluler " $\mathrm{X}$ "

Sumber : Santouridis \& Trivellas (2010), Qayyum, Khang \& Krairit (2013)

Dari uraian yang dikemukakan pada keterkaitan antara variabel di atas, maka secara praktis model penelitian dalam penelitian ini adalah sebagai berikut : 


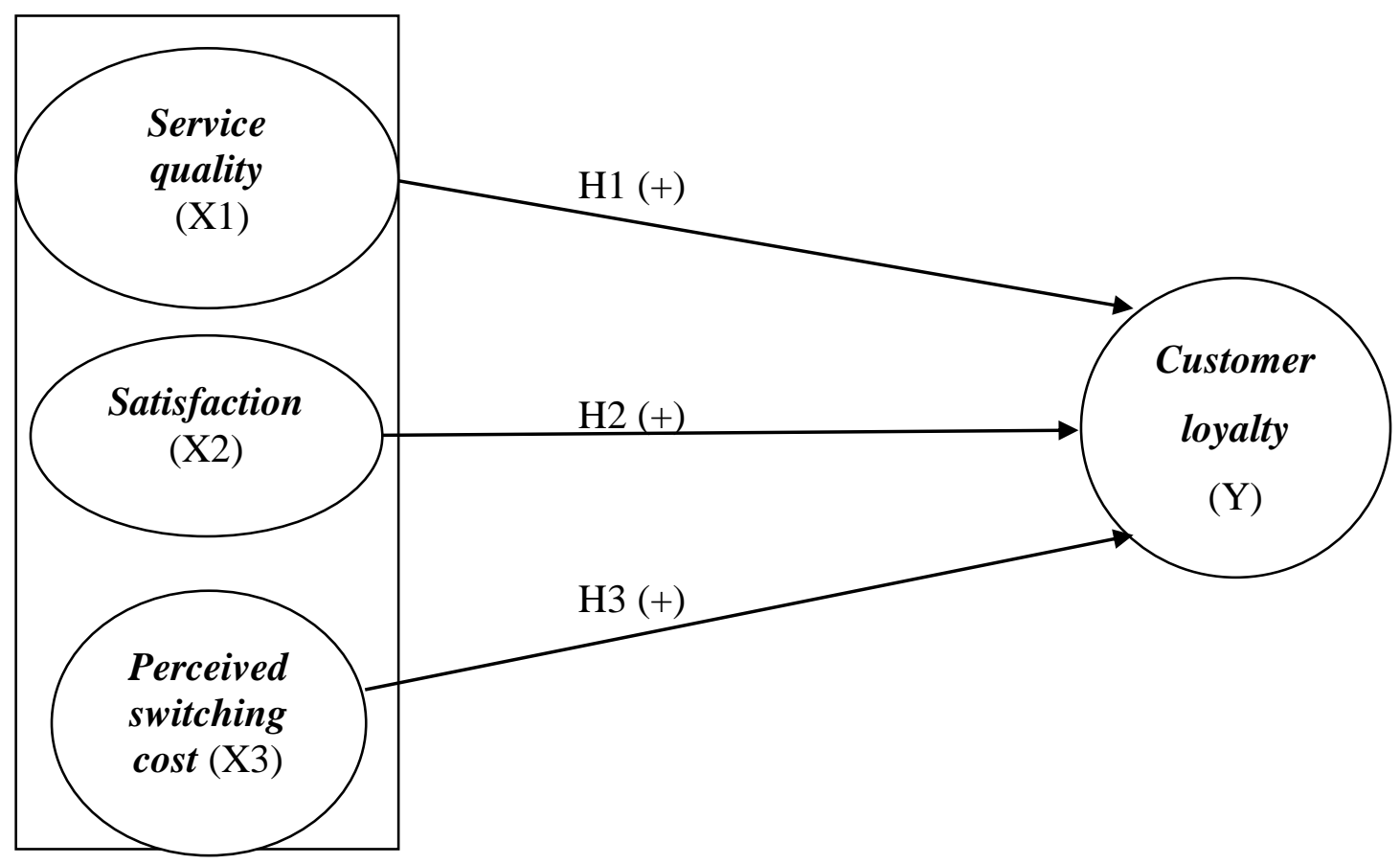

Gambar 2 Model penelitian

Terdapat 3 hipotesis dalam penelitian ini yang diperoleh dari penelitianpenelitian yang sebelumnya, di mana :

$\mathrm{H} 1:$ service quality memiliki pengaruh positif signifikan terhadap customer loyalty

$\mathrm{H} 2$ : satisfaction memiliki pengaruh positif signifikan terhadap customer loyalty

H3: perceived switching cost memiliki pengaruh positif signifikan terhadap customer loyalty

Sebelum dilakukan analisis regresi berganda, setiap butir indikator pada kuesioner tersebut harus melewati uji validitas dan reliabilitas terlebih dahulu terhadap masing-masing variabel dalam penelitiannya. Neuman (2011) mendefinisikan validitas sebagai kesesuaian yang terjadi antara konstruk yang digunakan pada suatu penelitian atau bagaimana peneliti mengkonseptualisasikan idenya ke dalam definisi konseptual dan suatu ukuran. Lebih singkatnya validitas membahas mengenai seberapa tepat indikator yang diukur dalam suatu penelitian terhadap konstruk dalam penelitian itu. Priyatno (2013) mengemukkakan bahwa syarat indikator dikatakan valid apabila nilai Corrected Item - Total Correlation diatas 0,3. 
Ghozali (2007), menyimpulkan bahwa reliabilitas (kehandalan) jawaban seseorang terhadap pernyataan yang stabil dari waktu ke waktu. Pengujian

\section{ANALISIS DAN PEMBAHASAN}

Deskripsi Subjek penelitian

Setelah indikator selesai disusun, maka kuesioner disebar kepada mahasiswa di sebuah universitas di Jakarta Barat, dengan klasifikasi subjek responden tersebut adalah sebagai berikut :

1. Jurusan

Sebanyak 42 responden adala mahasiswa jurusan Manajemen dan 8 responden adalah mahasiswa jurusan Akuntansi.

2. Semester

Sebanyak 22 responden dalam reliabilitas ini diuji dengan melihat besarnya nilai Cronbach's Alpha, dikatakan reliabel apabila nilai Cronbach's Alpha > dari 0,6.

penelitian ini adalah mahasiswa semester 1 sampai 2, sebanyak 10 responden merupakan mahasiswa semester 3 sampai 4, dan sisanya adalah mahasiswa semester 5 ke atas.

Uji Validitas \& Uji Reliabilitas

Setelah kuesioner disebar, maka kuesioner tersebut diolah datanya dan dilakukan uji validitas dan uji reliabilitas terhadap indikator-indikator dari masing-masing variabel tesebut, berikut hasil pengujiannya.

Tabel 5 Uji Validitas Service quality $\left(\mathrm{X}_{1}\right)$

\begin{tabular}{lc}
\multicolumn{1}{c}{ Indikator } & Hasil \\
\hline Kejelasan suara & 0,530 \\
Cakupan area operator & 0,498 \\
Operator memperlakukan saya dengan baik ketika terjadi keluhan & 0,605 \\
Operator memberikan layanan tambahan yang bervariasi & 0,593 \\
$\begin{array}{l}\text { Operator memberikan pelayanan yang reliabel (konsisten) seperti yang } \\
\text { dijanjikan }\end{array}$ & 0,721 \\
$\begin{array}{l}\text { Staf operator seluler "X” melayani saya dengan baik ketika saya } \\
\text { berkunjung ke kantor operatornya }\end{array}$ & 0,619
\end{tabular}


Tabel 6 Hasil Uji Validitas Satisfaction $\left(\mathrm{X}_{2}\right)$

\begin{tabular}{ll}
\multicolumn{1}{c}{ Indikator } & Hasil \\
$\begin{array}{l}\text { Secara keseluruhan saya puas terhadap kualitas yang diterima dari } \\
\text { operator seluler "X" }\end{array}$ & 0,836 \\
$\begin{array}{l}\text { Secara keseluruhan saya puas terhadap pelayanan yang ditawarkan oleh } \\
\text { perusahaan }\end{array}$ & 0,748 \\
$\begin{array}{l}\text { Pilihan yang bijak untuk menggunakan operator seluler "X" } \\
\text { Memilih operator "X" merupakan sebuah pilihan yang tepat }\end{array}$ & 0,623 \\
\hline & 0,516 \\
\hline & Tabel 7 Hasil Uji Validitas Perceived switching cost $\left(\mathrm{X}_{3}\right)$ \\
$\quad$ Indikator & 0,511 \\
$\begin{array}{l}\text { Mengganti operator seluler lain akan memberikan biaya tambahan } \\
\begin{array}{l}\text { Saya tidak yakin bahwa operator seluler lain dapat memberikan tarif } \\
\text { yang lebih murah }\end{array}\end{array}$ & 0,765 \\
$\begin{array}{l}\text { Untuk berpindah ke operator lain, saya akan membandingkan dari segi } \\
\text { pelayanan, tarif, area cakupan dsb }\end{array}$ & 0,734 \\
$\begin{array}{l}\text { Jika saya mengganti operator seluler lain, operator tersebut belum tentu } \\
\text { dapat memberikan kualitas seperti yang saya harapkan }\end{array}$ & 0,661 \\
$\begin{array}{l}\text { Walaupun saya sudah mempunyai berbagai informasi, membanding- } \\
\text { bandingkan operator seluler lain membutuhkan waktu, tenaga, usaha }\end{array}$ & 0,585 \\
$\begin{array}{l}\text { Saya memikirkan orang yang tidak dapat menghubungi saya akibat } \\
\text { saya mengganti nomor handphone yang baru }\end{array}$ & 0,521 \\
\hline
\end{tabular}

Tabel 8 Hasil Uji Validitas Customer loyalty (Y)

\begin{tabular}{lc}
\multicolumn{1}{c}{ Indikator } & Hasil \\
Saya akan merekomendasikan operator seluler "X" ke orang lain & 0,508 \\
Saya akan terus menggunakan operator seluler "X" & 0,525 \\
$\begin{array}{l}\text { Walaupun operator merek lain lebih murah, saya akan tetap } \\
\text { menggunakan operator seluler "X" }\end{array}$ & 0,485 \\
Jika saya membeli nomor handphone baru, saya akan memilih operator & 0,395 \\
seluler "X"
\end{tabular}

Dari hasil uji validitas di atas antara tabel 5 , tabel 6 , tabel 7 dan tabel 8 menunjukkan bahwa semua indikator sudah valid karena hasilnya di atas 0,3 sehingga dengan demikian instrumen pernyataan akan dilanjutkan dengan pengujian reliabilitas.

Tabel 9 Uji Reliabilitas

\begin{tabular}{lc}
$\quad$ Variabel & Cronbach's $\boldsymbol{\alpha}$ \\
Service quality & 0,818 \\
Satisfaction & 0,821 \\
Perceived switching cost & 0,843 \\
Customer loyalty & 0,690 \\
\hline
\end{tabular}


Sedangkan untuk hasil pada tabel 9 menunjukan bahwa nilai Cronbach's

Alpha $>0,6$. Sehingga dengan demikian semua variabel maka dapat dikatakan sudah reliabel.

Uji Asumsi Klasik Data

Gambar 3 Normalitas

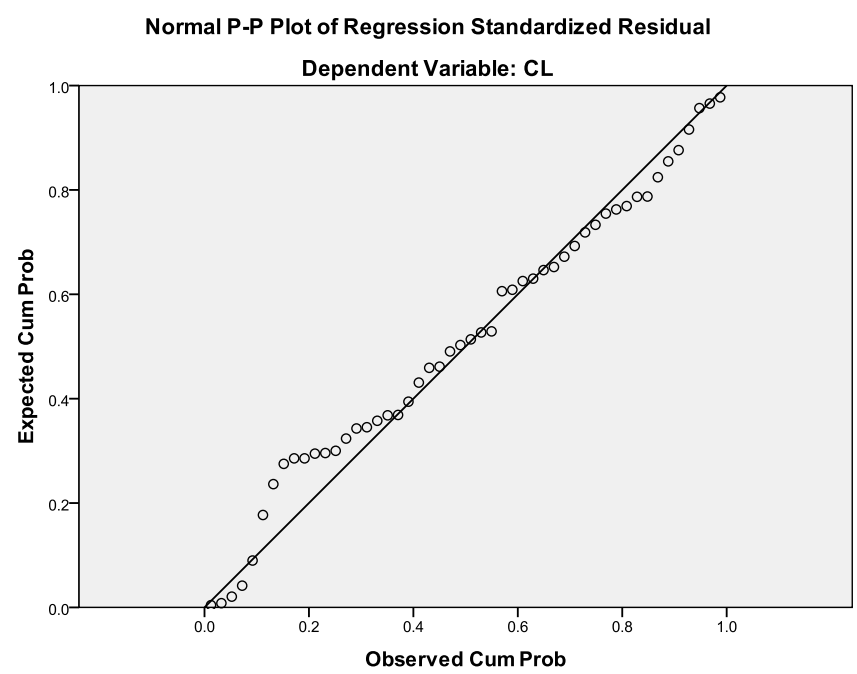

Gambar 3 menunjukkan titik-titik menyebar di sekitar garis diagonal, maka dapat disimpulkan bahwa data penelitian ini terdistribusi secara normal.

Multikolinearitas

Tabel 10 Uji multikolinearitas

Collinearity Statistics

Tolerance Tolerance

\begin{tabular}{rr}
.532 & .532 \\
.795 & .795 \\
.641 & .641 \\
\hline
\end{tabular}

Tabel 10 dilakukan uji multikolinearitas

$(V I F)$ seluruhnya bernilai < 10 , maka di mana nilai Variance Inflation Factor multikolinearitas tidak terjadi. 
Gambar 4 Heteroskedastisitas

Scatterplot

Dependent Variable: $C L$

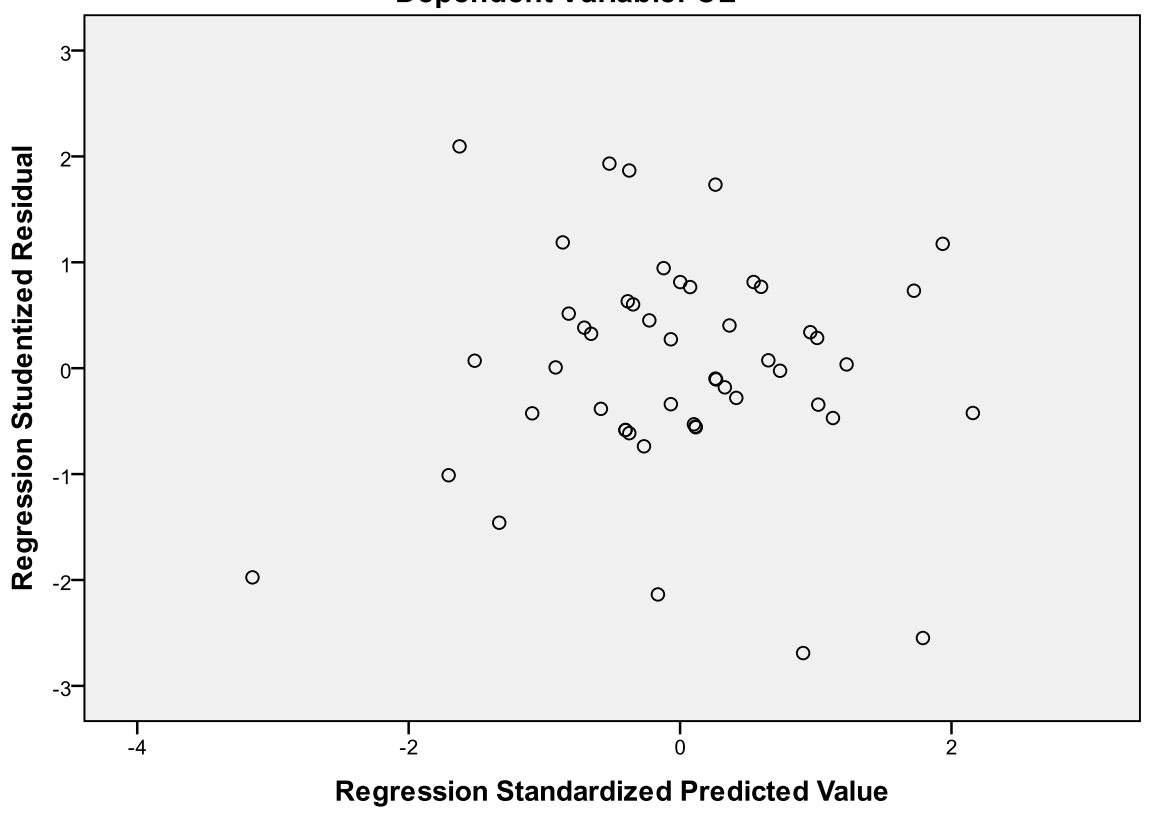

Pada gambar 4 menunjukan di mana demikian bahwa heteroskedastisitas bahwa titik-titik menyebar secara acak tidak terjadi.

tanpa pola yang jelas, sehingga dengan

\section{Uji Hipotesis}

Uji hipotesis dalam peneltian ini dilakukan dengan menggunakan uji t, dengan melihat hasil pada tabel 11 di bawah ini :

Tabel 11 Coefficients $^{a}$

\begin{tabular}{|c|c|c|c|c|c|c|}
\hline \multirow{2}{*}{\multicolumn{2}{|c|}{ Model }} & \multicolumn{2}{|c|}{$\begin{array}{c}\text { Unstandardized } \\
\text { Coefficients }\end{array}$} & \multirow{2}{*}{$\begin{array}{c}\text { Standardized } \\
\text { Coefficients } \\
\text { Beta }\end{array}$} & \multirow[b]{2}{*}{$t$} & \multirow[b]{2}{*}{ Sig. } \\
\hline & & B & Std. Error & & & \\
\hline \multirow[t]{4}{*}{1} & (Constant) & 3.262 & 1.284 & & 2.540 & .015 \\
\hline & SQ & .206 & .091 & .301 & 2.266 & .028 \\
\hline & PSC & .200 & .083 & .261 & 2.402 & .020 \\
\hline & CS & .293 & .086 & .410 & 3.392 & .001 \\
\hline \multicolumn{4}{|c|}{ a. Dependent Variable: CL } & & & \\
\hline
\end{tabular}


Dengan membandingkan nilai sig. di tabel 11, jika lebih kecil dari 0,05. Maka dapat kita simpulkan sebagai berikut :

1. $\mathrm{H}_{1}$ tidak ditolak, terdapat pengaruh positif signifikan service quality terhadap customer loyalty

\section{KESIMPULAN}

Melalui hasil pengujian di atas, diperoleh hasil bahwa dari ketiga variabel independen dalam penelitian ini, semuanya memiliki arah yang sama dan nilai signifikansi dengan hipotesis atau dengan penelitian yang sebelumnya. Dari variabel independen pertama service quality memiliki pengaruh positif signifikan terhadap customer loyalty yang sejalan dengan hipotesis dalam penelitian ini. Hal ini menandakan bahwa dalam industri operator seluler, service quality sangatlah berperan penting dalam menentukan loyalitas konsumennya. Baik dari segi area cakupan signal, suara yang jelas saat bercakap bertelepon, pelayanan yang baik dari si operator dalam memberikan penanganan keluhan, dsb. Sedangkan pada variabel independen kedua yaitu customer satisfaction memiliki pengaruh positif dan signifikan terhadap
2. $\mathrm{H}_{2}$ tidak ditolak, terdapat pengaruh positif signifikan customer satisfaction terhadap customer loyalty

3. $\mathrm{H}_{3}$ tidak ditolak, terdapat pengaruh positif signifikan perceived switching cost terhadap customer loyalty

tertinggi dibandingkan variabel independen lainnya. Hal ini menandakan pentingnya kepuasan konsumen terhadap penggunaan layanan operatornya untuk menambah loyalitas sehingga tidak berpindah ke operator seluler lainnya. Variabel independen yang ketiga adalah switching cost memberikan efek positif signifikan ketiga terbesar dibandingkan variabel independen lainnya, hal ini mencerminkan bahwa tingkat loyalitas juga dapat dipengaruhi oleh perubahanperubahan harga dari pesaingnya, dan juga membanding-bandingkan dengan kompetitornya yang lain baik dari segi waktu, tenaga, dsb.

Saran

1. Untuk tetap mempertahankan atau meningkatkan loyalitas konsumen dapat dengan cara meningkatkan kepuasan konsumen melalui peningkatan kualitas, serta 
meningkatkan service quality seperti kejelasan suara, area cakupan, dsb. Yang terkahir untuk meningkatkan loyalitas dapat dengan cara meningkatkan perceived switching cost dengan mempertahankan harga yang sekarang.

2. Terbatasnya ruang lingkup yang diambil dalam penelitian ini yaitu hanya di area universitas yang ada di Jakarta Barat, tentunya untuk hasil yang lebih maksimal bisa

\section{DAFTAR PUSTAKA}

Alhaija, A. S. A., Yusof, R. N. R., Hashim, H., Jaharuddin, N. S. (2018). "Determinants of Customer Loyalty: A Review and Future Directions". Australian Journal of Basic and Applied Sciences. Vol 12 (7) : 106-111

Andaleeb, Syed Saad \& Conway, Carolyn. (2006), "Customer Satisfaction in Restaurant Industry : an Examination of the Transaction Specific Model". Journal of Services Marketing.

Aritonang, R. Lerbin, R. (2007). Teori dan Praktik Riset Pemasaran. Bogor: Ghalia Indonesia

Avgeropoulos, Stephanos \& Bonnici, T. S. (2014). Wiley Encyclopedia of Management, edited by Professor Sir Cary L Cooper. mengambil sampel lebih besar lagi ruang lingkupnya bisa di Jakarta atau pun ruang lingkup yang lebih besar.

3. Penambahan sampel dalam penelitian untuk meningkatkan tingkat keakuratan hasil dari penelitian ini juga diperlukan, disarankan untuk mengambil sampel yang lebih besar agar hasil penelitian dapat lebih maksimal.

Ganguli, Shirshendu \& Roy, S. K. (2011). "Generic technologybased service quality dimensions in banking". International Journal of Bank Marketing Vol. 29 (2) : 168-189

Ghozali, Imam. (2007). Analisis Multivariate dengan program PASW. Semarang: Badan Penerbit Universitas Diponegoro.

Hafeez, Samraz \& Muhammad, Bakhtiar. (2012). "The Impact of Service Quality, Customer Satisfaction and Loyalty Programs on Customer's Loyalty: Evidence from Banking Sector of Pakistan". International Journal of Business and Social Science Vol. 3 (16) : 200-209 
Khan, Inamullah. (2012). "Impact of Customers Satisfaction And Customers Retention on Customer Loyalty". International Journal of Scientific \& Technology Research Vol. 1 (2) : 106-110.

Nasution, M. E. \& Usman, Hardius. (2007). Proses Penelitian Kuantitatif. Jakarta : Lembaga Penerbit Fakultas Ekonomi Universitas Indonesia

Neuman, W.L., (2011) Basic of social research: Qualitative and Quantitative Approach. Boston: Pearson Education, Inc.

Priyatno, Duwi. (2013). Mandiri belajar analisis data dengan SPSS. Mediakom.

Qayyum, A., Khang, D. B., Krairit, D. (2013). "An analysis of the antecedents of loyalty and the moderating role of customer demographics in an emerging mobile phone industry". International Journal of Emerging Markets. Vol. 8 (4) : 373-391

Santouridis, Ilias \& Trivellas, $P$. (2010). "Investigating the impact of service quality and customer satisfaction on customer loyalty in mobile telephony in Greece”. The TQM

Journal. Vol. 22 (3) : 330-343

Sekaran, U. and Bougie, R. (2013). Research Methods for Business-A Skill Building Approach. 6th Edition, John Wiley and Sons

Shah, S. H. A., Gul, S., Shakir, H., Qureshi, I. (2013). Switching Cost and Consumer Behaviour: A Structural Analysis of Telecom Sector of Pakistan. World Applied Sciences Journal. Vol. 28 (4) : 513-527

Tarus, D. K., Rabach, Nicholas (2013). "Determinants of customer loyalty in Kenya: does corporate image play a moderating role?". The TQM Journal. Vol. 25 (5) : 473-491

Tuan, N. P. \& Linh, N. T. H. (2014). "Impact of Service Quality Performance on Customer Satisfaction : A case study of Vietnam's Five Star Hotel". ABAC Journal Vol. 34 No. 3

https://tekno.kompas.com/read/2019/07/ 03/11050027/ini-daftarkecepatan-internet operatorseluler-di-indonesia 